\title{
Traditional Transport Tools as Supporters of the Regional Economy through Tourism and Culture Activities
}

\author{
E R Gultom ${ }^{1}$
}

${ }^{1}$ Law Faculty, Trisakti Jakarta university

\begin{abstract}
Some regions in Indonesia such as West Sumatra, Yogyakarta, Jakarta and other regions, often found traditional Bendi transportation which is used to transport people or goods from one place to the agreed destination. Apart from functioning as a public transportation tool, Bendi also has an important role in tourism, which is used around to transport tourists both from within and outside the country. The activity carried out by Bendi can increase the income of the local people who use Bendi as a regional tourism promotion tool. How is the existence of a Traditional Transport Tool in the midst of modern transportation in Indonesia?; How is this traditional Bendi transport regulated in Indonesia's national regulations? and What is the support of traditional Bendi transportation for regional economic development where its position is as a means of transportation? Is the subject matter in writing this paper. The research method used is normative, using secondary data and primary data as supporters, through interviews with some observers of traditional transport equipment. Then it will be analyzed descriptively. The conclusion obtained is that in a certain area, there are provisions for regional regulations that regulate the existence of these Bendi traditional transportation equipment, such as in the Yogyakarta area. Traditional Bendi transportation support as a supporter of the regional economy through tourism activities is very large, such as those found in the Yogyakarta area, where Bendi is always there to surround tourist areas that deliver domestic and foreign tourists in visiting tourist areas, as well as in West Sumatra , Padang, Bendi still exists even though it is rare, but it is still used as a tourism and cultural transport tool.
\end{abstract}

\section{Introduction}

Transportation in essence is to move people or goods from the place of origin to the destination safely, and the transfer is needed to achieve and increase benefits and efficiency $\{4\}$. Indonesia knows many transportation or transportation tools, whether it's short or far away. The types of transportation known are land, sea and air. There are transportation equipment or modern transportation and traditional transportation that have their own characteristics .

The diversity and richness of Indonesian culture is invaluable, from customs, folk songs, food, tourist attractions, and not including transportation in Indonesia. All of them each have their own characteristics and are truly authentic from Indonesia. Traditional Indonesian transportation equipment has a very valuable value and has an important position because it is part of Indonesia's cultural heritage.

At present there are so many modern modes of transportation popping up, even online and this makes the traditional transportation modes more backward. Just mention the traditional transportation modes such as rickshaws, bicycle ojek, delman, gig or bendi which in this paper are referred to as one of the designations of a trandisical conveyor with three or four wheels, not using engines but horses as a substitute for the subject. The distinctive feature of this traditional conveyance is that it has four wheels to be stable and balanced when walking, with a relatively large shape, and is sometimes pulled by two horses or just one horse, controlled by a driver behind the horse. 
The names of this traditional transport equipment vary according to the area where the transport is located, in the Sukabumi area called Nayon, in Yogyakarta called Dokar, in Solo or Klaten, Malioboro, Ngasem Market, and Kotagede called Andong. In West Sumatra, precisely Minangkabau and North Sulawesi are called Bendi.

This traditional conveyance has the potential that can be used optimally, but currently it cannot be implemented, even though the uniqueness and originality of the transportation of the dam can be a symbol or symbol of an area that can boost the economy of the area where the transportation is available, namely increasing the number of foreign or domestic tourists to come to tourist cities in Indonesia. Indirectly the existence of a bendi as a traditional conveyance is a form of uniqueness from the area where the transportation equipment is located. This traditional transportation tool is used for transporting short distances or in rural areas that are regional or in rural areas.

In some regions, it is precisely in the tourist area and permitted to operate, but must follow the existing rules, such as paying attention to the cleanliness of the environment in place. The Regional Government recognizes the existence of traditional transportation equipment with the issuance of regional regulations by the Local Government.

These things are the rationale for discussing the potential of traditional bendi transportation equipment to increase the income of the surrounding community from the area where it operates in certain areas that have been regulated by the local government through its regional regulations.

\section{A. Problems}

Based on the background above, the formulation of the problem from this paper is:

1. What is the existence of this traditional transport vehicle in the midst of the flow of modern transportation in Indonesia?

2. How is this traditional transportation regulated in the regulations in Indonesia?

3. How is this traditional transportation support for regional economic development where its position is as a means of transportation?

\section{B. Purpose of Writing}

Based on the formulation of the problem above, the purpose of this paper is to describe the following:

1. Regarding the existence of traditional transportation equipment that uses animal horses in Indonesia;

2. Regarding Indonesia's national rules that underlie the operation of traditional transportation;

3. About the potential of this traditional transportation to the economic development of the region where its position is as a means of transportation.

\section{Benefits of Writing}

The writing of this paper is useful to illustrate the potentials that can be extracted from the existence of traditional bendi transportation, among others for the community, namely increasing the income of the community around the area where the dam is operating and benefiting from increasing community activities that automatically increase local income through regional tourism potential. seeded and can attract foreign and domestic tourists who automatically increase the potential of the area's natural tourism.

\section{Results and Discussion}

\section{About traditional transportation equipment that uses animal horses}


Transportation plays an important role in social life and society and is very helpful in providing facilities and facilities, namely (benefits of transportationwww.pinterdw.blogspot.co.id):

a. Services for individuals and groups;

b. Exchange and delivery of information;

c. Personal and social travel;

d. Shorten travel time between home and work place;

e. Support the expansion of the city or the spread of the population into smaller groups.

To carry out all the activities of interest above, transportation or transportation tools are needed. Transport is a means to help individuals or groups reach out to various destinations, or send goods from the place of origin to the place. Every transportation activity that is categorized as both personal and public has the purpose of carrying out good and proper transportation services for the community, and especially important is to get to the destination safely.

Transportation has an important role in people's lives. Law No. 22 of 2009 concerning Road Traffic and Transportation, that "road traffic and transportation has a strategic role in supporting national development and integration as part of efforts to advance public welfare as mandated by the 1945 Constitution of the Republic of Indonesia".

Bowersox states, "Transportation is the transfer of goods or people from one place to another, where the product is moved to the required destination" (Bowersox-1981). Salim stated, "transportation is a means for humans to move something either people or objects from one place to another, with or without using tools". The tools used can be in the form of human, animal, nature or other objects using machines or not machined.

The history of mobile transportation starts from carrying goods or passengers using animal power facilities, to make it easier to move goods, using animal power such as cattle, buffaloes and horses. But what has survived until now is the horse. Used horsepower to facilitate the movement of people and goods from one place to the destination. The traditional conveyance is a bendi, besides the name applies another name based on the known transport area.

For example, in the Yogyakarta area, the area uses transportation with the help of horsepower as a public transportation tool. The name known is andong, is one of the transportation transports in Yogyakarta. Andong is a transport or transportation vehicle that uses or utilizes animal power, namely horses. At present, andong can be enjoyed from all walks of life regardless of social status, as in the past, only officials and courtiers can use it. Andong can be found along Malioboro, Bringharjo market, the north square of Yogyakarta city and Parangtritis tourism to surround the beautiful beach. Andong in Yogyakarta can be divided into 2 (two) types, namely horse cart for tourism and non-tourism $\{15\}$

2. Traditional Transport Equipment that uses Horse Animal Power drawn by a Coach, About its existence in various regions, Symbol of Specificity and Uniqueness in a Region

Several researchers, including, have carried out several studies on traditional transportation equipment: Yuni Astuti $\{5\}$, entitled "The Existence of Becak Transportation in the Development of Transportation in Yogyakarta". The study concluded that pedicabs in the Yogyakarta area are still used by the community as an alternative means of transportation even though there are many modern transportation. Rismawati $\{2\}$, who conducted a study on "The Existence of Delman (Keretek) Transportation Equipment on the Life of the Coachman 
Delman in Majalaya District, Bandung Regency". This study revealed the social and economic conditions of the coachman.

The passage of time proves, even though many modern transports have sprung up even online, the existence of traditional dam transportation is not lost by time, even strengthened by the existence of regions, which further strengthens it as a symbol of the distinctiveness of the region. This is evident, the existence of traditional transportation equipment that uses horsepower and is controlled by a coachman.

Even though at present the traditional transportation equipment is marginalized due to modern transportation equipment, there are many benefits to using traditional transportation equipment, including:

a. Environmentally friendly and does not cause air pollution because it does not use fuel;

b. More economical in terms of manufacturing costs and in operation;

c. Its existence as a means of cultural preservation that has distinctiveness and uniqueness

The name of the Traditional Transport that uses Horses as its attracting force varies from region to region, namely:

a.Andong is the name in Yogyakarta, Solo and the surrounding areas such as Klaten, Karanganyar, Sukoharjo, Boyolali and Salatiga. Regional officials and Dutch people can only use ancient times. But now, as time goes on, its existence is actually used for the benefit of the local community, which requires a dam service to deliver to certain areas that pass through alleys or narrow roads that are not too far away, or to deliver mothers and children. children in the neighborhood. Andong continues to exist, although there are many modern transportation equipment everywhere. It still survives because there are still many people preserving its existence because it is one of the Javanese cultural heritages.

b. In the Minangkabau area, no less important is the function and potential of this bendi. The existence of bendi has a very important role in the history of transportation in the Minangkabau in the past. Even though it was once an important transportation tool in Minangkabau, even in a Minang song that accompanies the paying dance, there is the lyrics "Babendi-bendi ka tanang river, stop by mangiak bungo lambayuang". The lyrics suggest that the bendi used to be a traditional conveyance that was very popular with Minangkabau people.

c.In Jakarta the name Bendi is known as Delman. Its existence is still recognized by the community with frequent use in the afternoon or when school children are enjoying school holidays. At around four to five in the afternoon, there was a clattering sound accompanied by the run of the horse's legs which were controlled by a driver sitting in the front, carrying passengers consisting of children and even mothers, to surround the village, say in the Warakas area in North Jakarta. Even at Monas, Delman or Bendi will appear on certain days, especially when the city of Jakarta welcomes its birthday.

d. In West Sumatra, wealthy merchants, regional officials such as demang, assistant demang and so on, only used horse-powered transportation controlled by a coachman. However, at this time with the passing of time, the Bendi has turned functions into public vehicles that are used by the community in short-distance environments, such as delivering mothers to the Market and children going to school. 
e.In the area of West Nusa Tenggara it is known as Cidomo, which stands for CikarDokar-Mobil ". Its use is more emphasized on short-distance environmental transportation or in rural areas that are regional in nature between villages.

f. In North Sulawesi, Manado traditional transportation is known as Bendi. Its presence attracted the attention of many people, and was used to get around in nearby areas for sightseeing around villages in certain areas.

g. Dokar is the term in West Java. Dokar is one of the developments of the Delman or Bendi transportation equipment. In the past this vehicle was called Dog-Car in the colonial era. The mention of the animal is wrong, because what's interesting is the horse. But along with the time the replacement of the designation became Dokar, whose existence spread almost all over Java Island with some form modifications, but with the same pattern of course.

\section{Traditional Transport Tools that use animal horses and their localized wisdom}

Traditional transport equipment that uses trains with the help of animal power as a puller and is controlled by a coachman has high potential. This is because its uniqueness and distinctiveness can take the hearts of its users to use its services to deliver to the desired areas of the environment.

In Minangkabau, these transportation equipment are very popular with the people even though many modern means of transportation are growing and developing. The local City Government because of its uniqueness and originality preserves its existence. It is imperative that this can be a potential in the city of Minangkabau and other areas in West Sumatra.

In the city of Manado, the official of the Governor of North Sulawesi, Soni Sumarsono, was very enthusiastic about the existence of these traditional transportation equipment. Even lifting the traditional transportation equipment called Bendi as the local wisdom of the area, as one of the means of transportation of the Minahasa community, which is now starting to fade.

\section{Traditional Transport Tools and Tourism Potential}

Although the existence of these traditional transportation equipment continues to be pushed in with the presence of modern transportation equipment, its existence is still maintained in several important cities, for example in West Sumatra, including among them in the city of Payakumbuh. Sometimes as a traditional conveyance, Bendi in West Sumatra has neofungsionalisasi, namely sometimes as a means of human transportation, and sometimes also as a support for tourism developed by the city government $\{6\}$. Tourism potential in West Sumatra is very high, let alone enlivened with the uniqueness and distinctiveness of Bendi as a traditional conveyance that has high added value for tourism development.

Many tourist areas in West Sumatra where bendi can operate, say in the Bukit Tinggi area, tourist areas include Banto Market, Pasar Bawah, Pasar Atas, Jam Gadang, and others. For the stop or base of the bendi has been provided in this tourist city. So the Bendi is not only a transportation for the local community, it is also used for tourism transportation and 
the Bukittinggi city government is very supportive for preserving and cultivating the potential of the dam as a means of transportation.

In Yogyakarta, many efforts have been made to increase the potential of bendi to support regional tourism and to be developed in conjunction with efforts to organize the local area's historic area. At present Yogyakarta is conserving traditional bendi transportation empowerment, because it is a traditional transportation that is feasible and environmentally friendly. So bendi is an emission free vehicle and must be conserved (16).

\section{Traditional transportation equipment and community income}

The existence of Traditional Transport Equipment pulled by Horse animals, greatly helps the economic wheel of the people in the area where the conveyance operates. Like in the area of West Sumatra, with the existence of bendi the community was greatly helped because of the great interest of the tourists to use this traditional transportation service that will transport where these tourists want to visit places of interest. The local city government, to facilitate and this have also provided the place of dismissal in order to support tourist charm in West Sumatra.

Environmental hygiene is also noted, how the horse that pulls this bend when removing waste does not pollute the streets and reduce environmental pollution. The City Government also provides solutions that make it easier for the Coachmen, namely people who drive a bendi to help maintain the cleanliness of the environment by keeping the stools from Horses whose energy is used to pull the dam not scattered to pollute the environment that is passed.

Likewise in Yogyakarta tourist areas, such as in the Malioboro area, Parangtritis Beach has been provided by the local city government for a stop from Andong, so that when Andong services are needed by tourists both outside and within the country it is not difficult, because the special stops are .

In the tourist area of Lombok, West Nusa Tenggara, Cidomo operates in predetermined places, both for tourism and places to meet the needs of the people who need Cidomo's services.

In terms of tariffs, the city government in each region does not participate in determining the amount. This transport Tariff is determined based on an agreement between the driver, namely the Coach and Passenger or Consumer, while the government only conducts supervision.

\section{Regional Regulations and Existence of Traditional Transportation}

The city government in the area of each of these transports has established the existence of this traditional transportation, and is a local wisdom that must be preserved as a national cultural heritage, among others:

a. Governor of the Special Region of Yogyakarta, Special Region of Yogyakarta Regulation Number 5 of 2016 concerning Moda of Traditional Pedicab and Andong Transportation.

b. Article 1 number 5 states: "Andong is a Traditional Transportation Mode with wheels of 2 (two) or 4 (four) wheels drawn by horses. 
In Article 2 it is regulated about Traditional Transportation, namely: "guaranteeing the safety and smoothness of traffic on the road; guarantee the sustainability of the preservation of Traditional Transportation; regulate the arrangement and implementation of Traditional Transportation; improve the welfare of Operators and / or Drivers, "and other Articles which emphasize the importance of the existence and operation of traditional transportation.

c. Regional Regulation of Padang City Number 11 Year 2005 concerning Public Order and Peace of Society.

Article 1 number 13 states: "Bendi is a traditional vehicle that uses a horse as a driving force".

d. East Lombok Regency Government, East Lombok Regency Regional Regulation Number 7 of 2004 concerning Retribution for Non-Motorized Vehicles.

Article 1 number 6 states: "Non-motorized vehicles are vehicles driven by animal power;

Article 1 number 7 states: "Cidomo Dokar is a non-motorized vehicle drawn by animals and used to transport people".

e. Regional Regulation of Payakumbuh City Number 6 of 1998

f. Regional Regulation of Payakumbuh City Number 8 of 2006

\section{Conclusion}

Traditional transportation using horse power in Indonesia varies in its name according to the area where the transport is located, is highly recognized as a symbol or symbol of regional cultural heritage that must be preserved because it has a unique and unique as a means of transportation used to transport people from one place to the destination safely.

Indonesia's national rules that underlie the operation of traditional transportation are made to legally reinforce the legitimacy of this traditional transportation equipment to operate mainly in potentially tourism areas, which aim to develop regional tourism potential in Indonesia. Each region that permits the operation of traditional transport issues its regional regulations to support it, because its uniqueness can support the tourism potential of each region in Indonesia to attract tourists from both inside and outside the country to use traditional transportation services while enjoying the desired tourist areas in Indonesia. . Thus, it can support regional income through the tourism sector.

This traditional transportation has the potential to lift the economy of the region or region where its position is as a means of transportation, and to help the surrounding community to have income from the operation of these transport equipment.

\section{Reference}

[1]. Bowersox, C. 1981. Introduction to Transportation. New York: Macmillan Publising Co, Inc.

[2]. Rismawati, Lina. 2011. "Eksistensi Alat Transportasi Delman (Keretek) Terhadap Kehidupan Kusir Delman di Kecamatan Majalaya Kabupaten Bandung”. Skripsi FPIPS

[3]. Salim, Abbas, R.1973. Manajemen Transportasi. Jakarta: PT.Grafindo Persada

[4]. Soekardono.2986. Hukum Dagang Indonesia, Cetakan ke-III. Jakarta:Rajawali

[5]. Astuti, Yuni, 2010, "Eksistensi Angkutan Becak dalam Perkembangan Transportasi di Yogyakarta". Jurnal Ampta

[6]. Sofyan, Fikrul Hanif dan Arsa Dedi. 2017. "Kuta Bendi di Kota Payakumbuh, Sumatera Barat Hingga Akhir Abad ke-20".Jurnal Mozaik Humaniora

[7]. Nugroho, Arinto. 2017. "Aturan Penggunaan Becak Tradisional di Kota Surabaya”. Jurnal Unes 
[8]. Undang-Undang Nomor 22 Tahun 2009 Tantang Lalu Lintas dan Angkutan Jalan

[9]. Gubernur Daerah Istimewa Yogyakarta, Peraturan Daerah Istimewa Yogyakarta Nomor 5 Tahun 2016 Tentang Moda Transportasi Tradisional Becak dan Andong.

[10]. Peraturan Daerah Kota Padang Nomor 11 Tahun 2005 Tentang Ketertiban Umum dan Ketentraman Masyarakat.

[11]. Pemerintah Kabupaten Lombok Timur, Peraturan Daerah Kabupaten Lombok Timur Nomor 7 Tahun 2004 Tentang Retribusi Kendaraan Tidak Bermotor.

[12]. Peraturan Daerah Kota Payakumbuh Nomor 6 Tahun 1998

[13]. Peraturan Daerah Kota Payakumbuh Nomor 8 Tahun 2006

[14]. Http://www. Pinterdw.blogspot.co.id/manfaat-transportasi/ diakses tanggal, 5 November 2018

[15]. Http://yogyakarta.panduwisata.id/tranportasi/andong-kereta-kuda-yang-merakyat/diakses tanggal, 5 November 2018

[16]. Harian Bernas, Hendra Kurniawan, Senin, 15 Februari 2016 